\title{
Social Trends through the decades
}

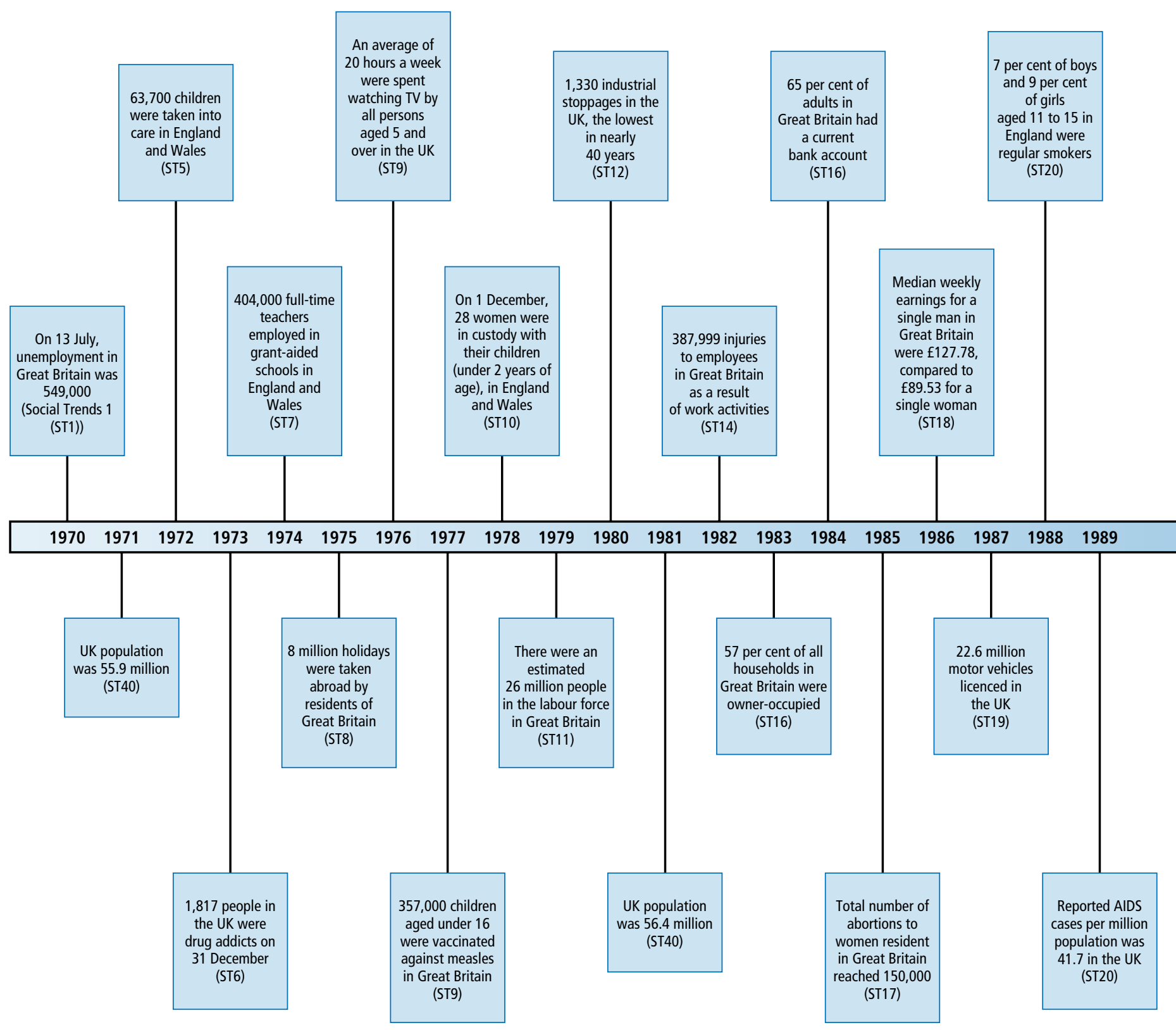




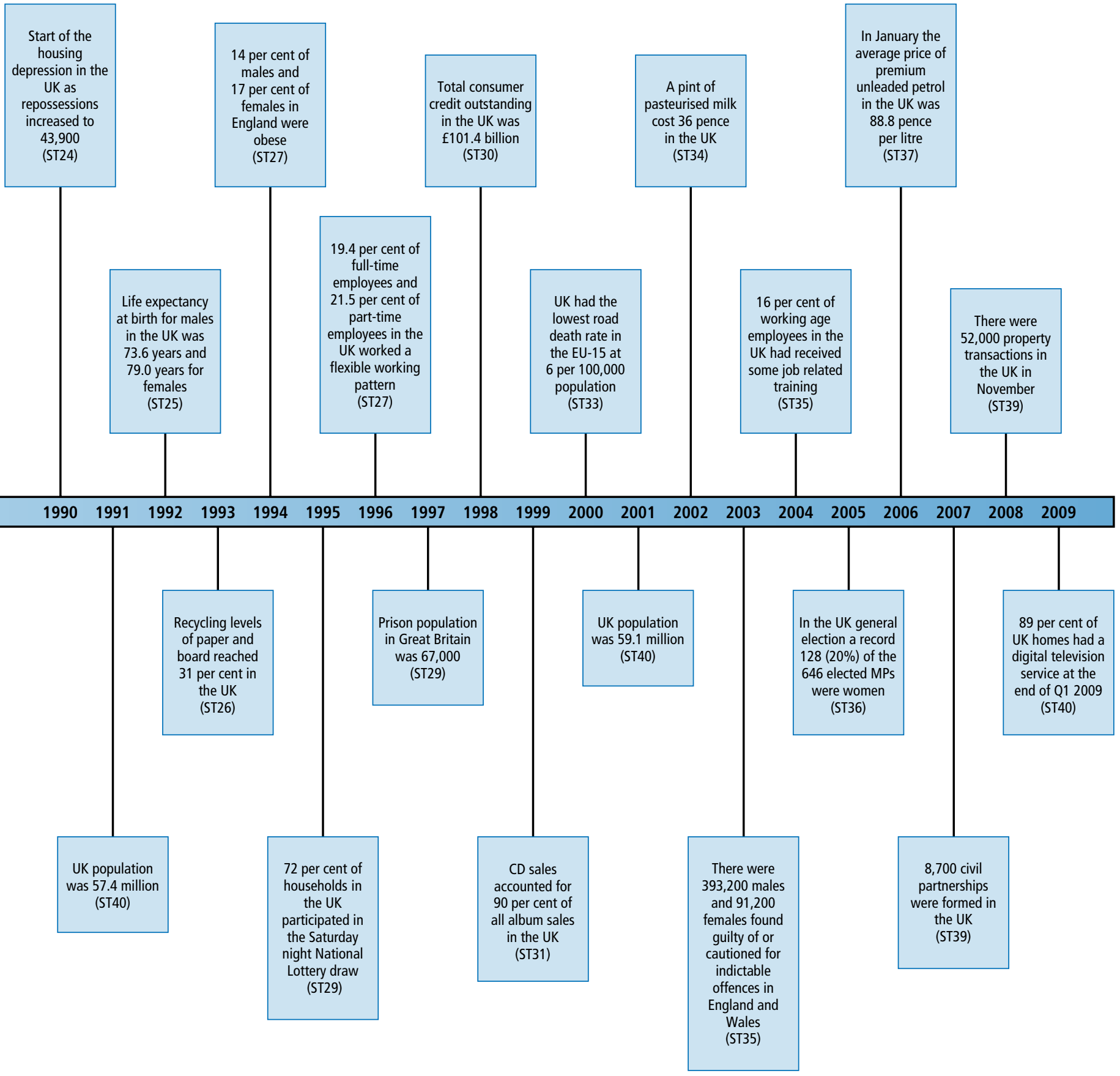




\section{Social Trends through the decades}

Anna Donabie, Matthew Hughes and Chris Randall

Social Trends 40 marks 40 years of social reporting in the UK. This publication has been one of the flagships of the Government Statistical Service since it was first published in 1970. In the first edition, Professor Claus Moser, the then Director of the Central Statistical Office, said in his article on developments in social statistics:

'Our aim is to bring together, initially once a year, a number of significant statistical series relating to social policies and conditions ... but even so the combination and confrontation of tables bearing on different aspects of social life may produce a more rounded picture of the social scene than now exists. If it is a success, Social Trends will help public understanding and discussion of social policy'.

This publication has indeed been a success and the Office for National Statistics are proud to publish Social Trends, and to continuously develop it. In this article we highlight some of the main changes over the past four decades since Social Trends began. Through each decade we will reflect on the statistics and commentary we reported on in these editions ${ }^{1}$.

\section{The 1970s}

The 1970s was a decade in which a wave of strikes paralysed the country, and the three day working week and winter of discontent became potent symbols.

The mid-1970s saw levels of unemployment not known in the UK since World War Two. In Social Trends 9, Table 5.12 highlighted the unemployment levels and rates over the decade. Unemployment rates in the UK increased from 3.5 per cent in 1971 to 5.7 per cent in 1976, before further rises to 6.0 per cent by quarter 2 (Q2) 1978. Working days lost in industrial disputes were also particularly high during this decade. The 1972 miners' strike was the first strike of British miners since 1926, and on 9 January all British miners came out on strike. In Social Trends 8, Table 5.23 (Table 1970.1) reported a total of 23.9 million days lost in the UK associated with labour disputes in 1972.

The majority (91 per cent) of these working days lost were a result of pay claims and disputes. The number of industrial disputes fell in 1973 before rising sharply in 1974 to 14.8 million. Again, this coincides with a decision by British miners to take industrial action. Their 1974 dispute lasted for 16 weeks.

The pattern of fuel used for energy generation changed during the period covering the miners' strike. In Social Trends 40, Figure 11.1 examines the trends in fuel used for electricity generation over the last 40 years. In 1970, coal was the most commonly used fuel for electricity generation in the UK, providing over 67 per cent of the fuel input. However, the provision of coal declined during the British mining strike periods and in 1972 and 1974 coal use accounted for 56 per cent of fuel input.

Measuring education participation and attainment has been a key feature of Social Trends since the first edition. In Social Trends 1 the tables and commentary provided trends in 'stock' or the total number of pupils in primary and secondary schools since the 1960s. Although attendance at school has not been compulsory until a child is five, throughout the decades Social Trends have highlighted the expansion of early years education in the UK. In Social Trends 40, Figure 3.1 examines the proportion of three and four-year-olds enrolled in all schools in the UK between 1970/71 and 2008/09. Since records began in the early 1970 s this proportion has increased from 21 per cent to 63 per cent. The number of early years places has also increased over the same period, from 723 state nursery schools in the UK in 1970/71 to 3,209 in 2008/09.

The 1970s was a period of expansion for the education system in the UK, a major event reported in Social Trends 7 was the raising of the school leaving age from 15 to 16 in 1972/73. Table 3.5 in Social Trends 7 examined the number of children at school by age of child. In 1971, prior to the raising of the

\section{Table 1970.1}

\section{Industrial disputes}

United Kingdom

\begin{tabular}{|c|c|c|c|c|c|c|c|c|}
\hline & 1966 & 1970 & 1971 & 1972 & 1973 & 1974 & 1975 & 1976 \\
\hline \multicolumn{9}{|l|}{ Working days lost: } \\
\hline Pay claims and disputes & 1.6 & 9.2 & 12.3 & 21.7 & 5.1 & 13.1 & 4.4 & 1.8 \\
\hline All other causes & 0.8 & 1.7 & 1.3 & 2.3 & 2.0 & 1.7 & 1.5 & 1.7 \\
\hline Total days lost & 2.4 & 10.9 & 13.6 & 23.9 & 7.1 & 14.8 & 5.9 & 3.5 \\
\hline
\end{tabular}

Source: Department for Employment 
Table 1970.2

\section{Secondary education}

\begin{tabular}{|c|c|c|c|c|c|c|}
\hline \multirow[t]{2}{*}{ England \& Wales } & \multicolumn{6}{|c|}{ Percentages } \\
\hline & 1970 & 1971 & 1972 & 1973 & 1974 & 1975 \\
\hline \multicolumn{7}{|l|}{ Public sector secondary schools } \\
\hline Middle deemed secondary & 1.2 & 1.8 & 2.3 & 3.7 & 4.6 & 5.4 \\
\hline Modern & 40.3 & 37.0 & 33.4 & 28.7 & 23.0 & 18.2 \\
\hline Grammar & 19.9 & 18.2 & 16.6 & 14.8 & 11.0 & 9.0 \\
\hline Technical & 1.4 & 1.2 & 1.0 & 0.8 & 0.6 & 0.5 \\
\hline Comprehensive & 30.8 & 35.9 & 41.1 & 47.0 & 57.4 & 64.3 \\
\hline Others & 6.5 & 5.9 & 5.5 & 5.1 & 3.3 & 2.6 \\
\hline All pupils (=100\%) (thousands) & $3,046.0$ & $3,143.9$ & $3,251.4$ & $3,362.6$ & $3,723.7$ & $3,826.6$ \\
\hline Average number of pupils per qualified teacher ${ }^{1}$ & 17.8 & 17.9 & 17.6 & 17.1 & 17.5 & 17.2 \\
\hline
\end{tabular}

1 Including full-time equivalent of part-time and visiting teachers.

Source: Statistics of Education, Volume I, Schools, Department of Education and Science

statutory minimum school-leaving age to 16 , there were

272,000 pupils aged 16 in schools in the UK, accounting for 3 per cent of the school pupil population. By 1974, the number of pupils aged 16 at school rose to 400,000 , accounting for 4 per cent of the pupil population.

Between 1965 and 1975 many secondary modern schools and grammar schools were amalgamated to form large neighbourhood comprehensives. By the mid-1970s, Social Trends reported on the closure of many grammar and modern schools and the amalgamation of the remainder into comprehensives. In Social Trends 7, Table 3.6 (Table 1970.2) reported a total of just over 3.0 million pupils in public sector secondary schools in England and Wales in 1970. Of these, the largest proportion (40.3 per cent) attended modern schools, while 30.8 per cent attended comprehensives and 19.9 per cent attended grammar schools. By 1975, the proportion of pupils attending comprehensive schools had reached 64.3 per cent, while there had been rapid declines in the proportions attending modern and grammar schools (18.2 per cent and 9.0 per cent respectively).

The introduction of the General Household Survey (GHS, now the General Lifestyle Survey) in 1970 provided regular data on the social conditions in Great Britain. Since the first edition the GHS has been an important source of information for Social Trends. Along with changes in the labour market and the education system, Social Trends in the 1970s highlighted a significant increase in the ownership of many consumer durables and household amenities. One change reported was the proportion of households owning a telephone, which increased from 35 per cent in 1970 to 52 per cent by 1975 .
Technological change in the 1970s was beginning to transform lives and was laying the foundations for the explosion of global communications in future decades. The 1970s marked a period of rapid developments in the telecommunications sector, many new services, such as international dialling were added. To support this expansion Post Office Telecommunications was set up as a separate department of the UK Post Office.

In Social Trends 10, Table 10.18 (Table 1970.3) examined the calls to information services reported by the Post Office. In 1970-71, a total of 366 million information service calls were made in the UK. Of these, 297.3 million calls were made to the speaking clock and 45.5 million calls to Dial-a-Disc, which enabled callers to listen to a song down a telephone line.

\section{Table 1970.3}

\section{Calls to information services}

\begin{tabular}{lrr} 
United Kingdom & & Millions \\
\hline & $1970-71$ & $1978-79$ \\
\hline Speaking clock & 297.3 & 431.2 \\
Dial-a-Disc & 45.5 & 110.3 \\
Weather & 11.6 & 29.0 \\
Cricket & 5.0 & 18.0 \\
Financial Times index & 1.4 & 4.0 \\
Motoring & 1.0 & 2.7 \\
Recipe & 2.7 & 2.3 \\
Teletourist & 1.1 & 0.6 \\
\hline
\end{tabular}

Source: Telecommunication Statistics, Post Office 
By 1978-79 these figures had increased to 431.2 million and 110.3 million respectively, possibly reflecting the larger number of households with a telephone.

Lifestyle choices in the UK were high on the household agenda during the 1970s. One way of illustrating changes in lifestyles is to look at how spending patterns changed during this decade. In Social Trends 9, Table 7.6 was able to examine patterns of change in consumer spending in the UK throughout the decade. Overall, consumers' expenditure fell in real terms between 1973 and 1977. Spending on items such as food, housing, water and fuel remained fairly stable throughout the 1970s. However, expenditure on less essential items - including communication, spending abroad, and recreation and culture - rose sharply. The largest category of expenditure in 1977 was food (£12.1 million), accounting for 19.5 per cent of total consumers' expenditure during that year. However, between 1970 and 1977, the largest proportional growth in consumer spending was on housing, which increased 2.6 percentage points to account for 15.4 per cent of consumer spending in 1977. Spending on transport and vehicles was the second largest increase (0.8 percentage points) over this period, and accounted for 12.5 per cent of consumer spending in 1977 , followed by spending on alcohol which increased by 0.5 percentage points and accounted for 7.8 per cent of consumer spending in 1977.

\section{The 1980s}

In 1979 unemployment stood at around 1.4 million, and the Conservative party swept to power on the message that 'Labour isn't working'. However, during the early 1980s, unemployment rose further still, topping 3.0 million in 1982. The two main factors behind the rise in the jobless total at the start of the 1980s were an economic recession with high inflation and industrial restructuring, which included closure of many factories in the UK's industrial heartlands.

As well as the high unemployment total, the duration of unemployment for many was also long. In Social Trends 15, Table 4.20 (Table 1980.1) showed the duration of incomplete spells of unemployment for unemployed claimants in April 1984 in the UK that were reported at the time. A quarter (24.6 per cent) of unemployed males aged 16 and over had been unemployed for over two years, while a further 18.9 per cent were unemployed for between one and two years. The proportion

Table 1980.1

Unemployed claimants: by sex, age and duration, April 1984

\begin{tabular}{|c|c|c|c|c|c|c|}
\hline & \multicolumn{6}{|c|}{ Duration of unemployment (weeks) } \\
\hline & Up to 2 & $\begin{array}{l}\text { Over } 2 \\
\text { up to } 8\end{array}$ & $\begin{array}{r}\text { Over } 8 \\
\text { up to } 26\end{array}$ & $\begin{array}{l}\text { Over } 26, \\
\text { up to } 52\end{array}$ & $\begin{array}{r}\text { Over } 52 \\
\text { up to } 104\end{array}$ & Over 104 \\
\hline \multicolumn{7}{|l|}{ Males aged: } \\
\hline $16-19$ & 5.8 & 12.8 & 28.0 & 29.4 & 18.8 & 5.1 \\
\hline $20-24$ & 5.2 & 10.9 & 23.9 & 20.5 & 18.6 & 20.9 \\
\hline $25-34$ & 4.6 & 9.8 & 21.6 & 17.8 & 19.2 & 27.0 \\
\hline $35-49$ & 4.3 & 8.8 & 19.6 & 16.4 & 19.1 & 31.8 \\
\hline $50-59$ & 3.6 & 6.5 & 16.9 & 17.3 & 20.5 & 35.3 \\
\hline 60 and over & 6.6 & 9.9 & 28.0 & 32.6 & 11.4 & 11.4 \\
\hline \multicolumn{7}{|l|}{ Females aged: } \\
\hline $16-19$ & 5.9 & 12.8 & 29.8 & 30.4 & 17.1 & 4.1 \\
\hline $20-24$ & 6.2 & 12.8 & 29.0 & 24.7 & 14.2 & 13.0 \\
\hline $25-34$ & 6.5 & 13.7 & 30.9 & 27.4 & 12.9 & 8.6 \\
\hline $35-49$ & 6.2 & 12.3 & 25.4 & 22.5 & 17.9 & 15.7 \\
\hline 50 and over & 3.3 & 6.5 & 16.3 & 18.4 & 22.0 & 33.5 \\
\hline All females aged 16 and over & 5.8 & 12.1 & 27.5 & 25.5 & 16.2 & 12.9 \\
\hline
\end{tabular}

Source: Claimant Count, Department of Employment 
of men who were long-term unemployed in April 1984 increased with age, 55.8 per cent of unemployed men aged 50 to 59 were unemployed for more than a year, compared with just under a quarter (23.9 per cent) of those aged 16 to 19. However, those aged 16 to 19 were helped by special training and employment measures that were around at the time.

The data for women was affected by women's entitlement to unemployment benefit at the time. But the table still shows that a higher proportion of older women were long-term unemployed with 55.5 per cent of unemployed women aged 50 and over unemployed for over a year. Overall, just under three in ten (29.1 per cent) unemployed women aged 16 and over were unemployed for over a year.

Social Trends 15 also included a table (Table A.2) from the 1983 British Social Attitude Series that showed the expectations of employees and unemployed people in Great Britain as to the estimated time to find an acceptable job. Just over a third (34 per cent) of employees thought that the estimated time taken to find an acceptable job from the time they became unemployed would be two months or less with a further 26 per cent estimating three to six months. While just under a fifth (19 per cent) of those unemployed thought that the estimated time taken to find an acceptable job from the time of their interview would be two months or less with a further 21 per cent estimating three to six months.

The 1980s will also be remembered for a new disease to come to the forefront of the medical world - Acquired Immune Deficiency Syndrome or AIDS, a disease of the human immune system caused by the Human Immunodeficiency Virus (HIV). The disease was first reported in the medical world in 1981. By 1982, there had been just seven reported cases of AIDS in the UK, compared to over 1,000 in the United States. It wasn't until 1987 that the first item about AIDS appeared in

Social Trends 17 (Figure 7.5). The item showed that around 400 cases had been reported by 1986 in the UK and of those cases around 200 people had died. In 1990, Social Trends 20, Table 7.9 contained more in-depth coverage in a table showing the number of HIV antibody positive reports, of which there were 10,794 to the end of June 1989, with 2,372 AIDS cases and 1,272 deaths. The chart also contained the exposure category which showed that the vast majority of HIV and AIDS cases were to homosexual and bisexual males.

A table in the article of Social Trends 19 (Table A.6) reported on attitudes to discrimination against AIDS sufferers from the 1987 British Social Attitude Series. It showed that nearly four in ten (38 per cent) adults aged 18 and over in Great Britain felt that there should be definitely or probably a legal right for employers to dismiss employees with AIDS. Just under a third
(31 per cent) felt that there should be definitely or probably a legal right for doctors and nurses to refuse treatment to AIDS sufferers and just under a quarter (24 per cent) felt that there should be definitely or probably a legal right for schools to expel children with AIDS.

Two government policies were popular with the general public in the 1980s. They were the privatisation of various nationalised industries and the associated shares bought by the public and the right to buy council homes. According to Social Trends 19, 8 per cent of the adult population owned shares only in privatised companies in 1988, including the Trustees Saving Bank Group (TSB). The substantial growth in share ownership began with the British Telecom privatisation in 1984 in which 2 million people bought shares. The TSB and British Gas flotation, in September and November 1986 attracted 3 million and 4.5 million shareholders respectively.

The legislation to implement the right to buy was passed in the Housing Act 1980. The sale price of a council house was based on its market valuation but also included a discount to reflect the rents paid by tenants and also to encourage take-up. The legislation gave council tenants the right to buy their council house at a discounted value, depending on how long they had been living in the house, with the proviso that if they sold their house before a minimum period had expired they would have to pay back a proportion of the discount. The sales were an attractive deal for many tenants and hundreds of thousands of homes were sold. According to Social Trends 19, sales of local authority and new town dwellings in the UK increased from about 93,000 in 1980 to over 228,000 in 1982 before falling back to 109,000 in 1986. Total sales reached 142,000 in 1987 and between 1980 and 1987 reached over one million.

A reflection of the times can be observed by looking at the durable goods that were owned in households. Table 1980.2 overleaf draws on two tables that appeared in Social Trends 13 (Table 6.12) and Social Trends 22 (Table 6.4) showing durable goods owned in 1981 and 1989-90 in Great Britain. In 1981, just under three-quarters (74 per cent) of households owned a colour television and under a quarter (23 per cent) owned a black and white television only. By the end of the decade the proportion of households owning a colour television had increased to 93 per cent and just 5 per cent owned only a black and white television. Ownership of a deep-freezer showed the largest percentage increase between the two dates (31 percentage points), from just under half (49 per cent) of households in 1981 to four-fifths (80 per cent) in 1989-90. Ownership of a home computer was also reported for the first time in Social Trends with just under one in five (19 per cent) households owning one in 1989-90. 
Table 1980.2

\begin{tabular}{|c|c|c|}
\hline \multirow[t]{2}{*}{ Great Britain } & \multicolumn{2}{|r|}{ Percentages } \\
\hline & 1981 & 1989-90 \\
\hline Colour television & 74 & 93 \\
\hline Telephone & 75 & 87 \\
\hline Washing machine & 78 & 86 \\
\hline Deep-freezer ${ }^{2}$ & 49 & 80 \\
\hline Video & .. & 60 \\
\hline Microwave oven &.. & 47 \\
\hline Tumble drier & 23 & 45 \\
\hline Home computer & .. & 19 \\
\hline CD player &.. & 16 \\
\hline Dishwasher & 4 & 12 \\
\hline Black and white television only & 23 & 5 \\
\hline Vacuum cleaner & 94 & .. \\
\hline Refrigerator $^{2}$ & 93 & .. \\
\hline Central heating & 59 & .. \\
\hline
\end{tabular}

1 Data is as reported in Social Trends 13 for 1981 and Social Trends 22 for 1989-90.

2 Includes fridge-freezers.

Source: General Household Survey, Office for National Statistics

Recently, the Treasury Committee launched an enquiry into the abolition of the cheque, which is scheduled for 31 October 2018. However, Social Trends 16 reported methods of payments for purchase of goods and services in 1984 in

\section{Table 1980.3}

\section{Household division of labour, $1987^{1}$}

Great Britain

Percentages

\begin{tabular}{|c|c|c|c|}
\hline & $\begin{array}{r}\text { Mainly } \\
\text { men }\end{array}$ & $\begin{array}{l}\text { Mainly } \\
\text { women }\end{array}$ & $\begin{array}{l}\text { Shared } \\
\text { equally }\end{array}$ \\
\hline Washing and ironing & 2 & 88 & 9 \\
\hline Looking after sick children ${ }^{2}$ & 2 & 67 & 30 \\
\hline Household cleaning & 4 & 72 & 23 \\
\hline Preparing evening meal & 6 & 77 & 17 \\
\hline Household shopping & 7 & 50 & 43 \\
\hline Teaching children discipline ${ }^{2}$ & 13 & 19 & 67 \\
\hline Doing evening dishes & 22 & 39 & 36 \\
\hline Organising household bills & 32 & 38 & 30 \\
\hline Repairing household equipment & 82 & 6 & 8 \\
\hline
\end{tabular}

1 Asked of respondents who were married or living as married.

2 Asked of respondents who were married or living as married and with children aged under 16 living in household.

Source: British Social Attitude Series, Social and Community Planning Research
Great Britain when using cheques was the main non-cash method of payment. There were 1,180 million cheque transactions compared with 610 million standing orders/direct debits and 280 million credit card transactions, while the debit card was yet to be introduced.

And finally in this decade, the age old question as to who does what in the home? According to Table A.9 in Social Trends 19, it was still overwhelmingly the case that the woman was responsible for looking after the house in Great Britain in 1987. Table 1980.3 shows that it was mainly the woman that performed household tasks like washing and ironing, looking after sick children or household cleaning. Only in repairing household equipment, organising bills and doing the evening dishes did men play a significant role.

\section{The 1990s}

The 1990s began with the continuation of the late 1980s economic downturn in which the UK saw interest rates rise. This in turn caused mortgage rates to rise from 9.8 per cent in the second quarter (Q2) of 1988 to 13.4 per cent a year later. The result of increased payments led to a rise in financial difficulties, arrears and repossessions in the late 1980s with the number of mortgages in arrears reaching a peak in 1992.

In Social Trends 29, Table 10.27 (Table 1990.1) reported a total of 76,000 properties repossessed in the UK in 1991 and a further 69,000 in 1992. The total number of mortgages in arrears in 1992 was 352,000, the highest number recorded to date.

The growth in technology in the 1990s showed an increase in the use of computers at work, at home and at school which began in the 1980s and continued throughout the 1990s, with the introduction of the World Wide Web which led to the dot-com boom in the mid to late 1990s.

Social Trends 27 reported the importance of computer use in schools showing that in secondary schools, word processing was the most common form of use in England in 1994, with 39 per cent of pupils' time using computers being spent for this purpose in Year 11.

Social Trends 29 reported the ratio of pupils to computers had fallen in England. In primary schools in 1993/94 there were 18 pupils per computer compared with 107 in 1984/85. Secondary schools had an even lower ratio with 10 pupils per computer in 1993/94 compared with 60 in 1984/85.

In Social Trends 29, Table 13.6 reported the increase in ownership of home computers, showing that the proportion of households in the UK with a home computer increased from 16 per cent in 1986 to 26 per cent in 1996-97. Households 
Table 1990.1

Mortgages, arrears and repossessions ${ }^{1}$

United Kingdom

Thousands

\begin{tabular}{|c|c|c|c|c|}
\hline & \multirow[b]{2}{*}{ Mortgages } & \multicolumn{2}{|c|}{ Loans in arrears at end-period } & \multirow{2}{*}{$\begin{array}{r}\text { Properties } \\
\text { repossessed } \\
\text { in period }\end{array}$} \\
\hline & & $\begin{array}{c}\text { By } 6-12 \\
\text { months }\end{array}$ & $\begin{array}{r}\text { By over } \\
12 \text { months }\end{array}$ & \\
\hline 1981 & 6,336 & 22 & .. & 5 \\
\hline 1982 & 6,518 & 27 & 6 & 7 \\
\hline 1983 & 6,846 & 29 & 8 & 8 \\
\hline 1984 & 7,313 & 48 & 10 & 12 \\
\hline 1985 & 7,717 & 57 & 13 & 19 \\
\hline 1986 & 8,138 & 52 & 13 & 24 \\
\hline 1987 & 8,283 & 56 & 15 & 26 \\
\hline 1988 & 8,564 & 43 & 10 & 19 \\
\hline 1989 & 9,125 & 67 & 14 & 16 \\
\hline 1990 & 9,415 & 123 & 36 & 44 \\
\hline 1991 & 9,815 & 184 & 92 & 76 \\
\hline 1992 & 9,922 & 205 & 147 & 69 \\
\hline 1993 & 10,137 & 165 & 152 & 59 \\
\hline 1994 & 10,410 & 134 & 117 & 49 \\
\hline 1995 & 10,521 & 127 & 85 & 49 \\
\hline 1996 & 10,637 & 101 & 67 & 43 \\
\hline 1997 & 10,738 & 74 & 45 & 33 \\
\hline
\end{tabular}

1 Estimates cover only members of the Council of Mortgage Lenders; these account for 98 per cent of all mortgages outstanding.

Source: Council of Mortgage Lenders

comprising families with children were more likely than one person households to own a computer, and in 1996-97 around two-fifths of households with children in the UK owned a computer compared with around a fifth of one person households aged 16 to 59, and only 2 per cent of those aged 60 and over.

The 1990s also saw the growth in the ownership and use of mobile phones. Although the first British mobile phone call was made on 1 January 1985, Social Trends did not report on the number of households with a mobile phone until towards the end of the 1990s, in Social Trends 29, Figure 13.7 (Figure 1990.2). In 1997-98, a fifth of households in the UK owned at least one mobile phone with ownership being most common among households headed by 45 to 54 -year-olds. Social Trends also reported that two-fifths of households headed by a professional owned a mobile phone compared with around 6 per cent of those headed by someone who was retired or unoccupied. The South East region had the greatest proportion of mobile phone owners where three in ten households owned

\section{Figure 1990.2}

\section{Households with a mobile phone: by age of head of household, 1997-98}

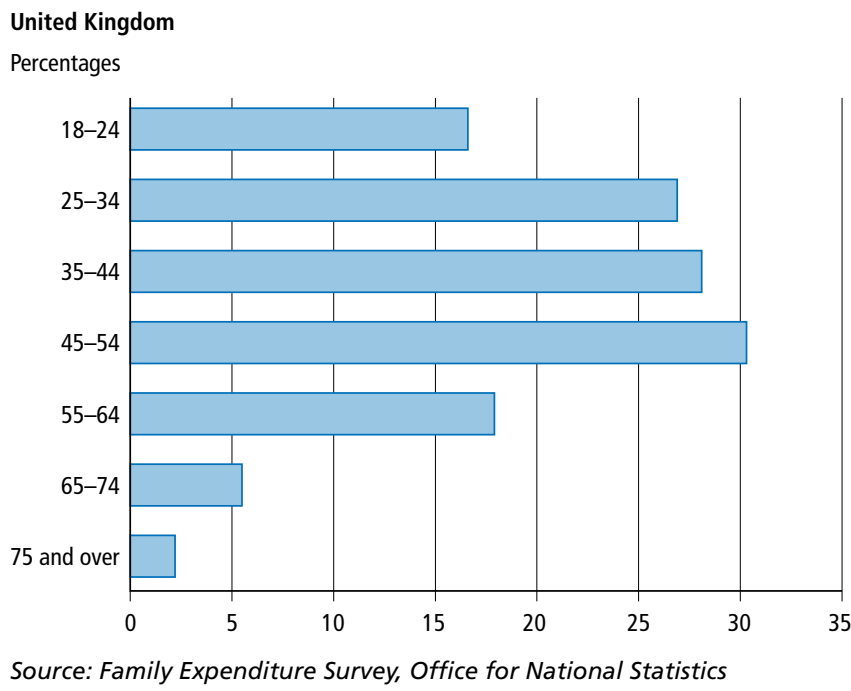

a mobile phone in 1997-98. In comparison, this edition of Social Trends reports that 79 per cent of households in the UK own a mobile phone (Chapter 6: Expenditure, Figure 6.9).

Throughout the decades Social Trends has reported on various aspects of transport and travel throughout Britain, reporting on the rise in car ownership and the decline in the use of public transport, together with increasing costs of motoring.

October 1994 saw a new alternative to air and sea travel when a limited car carrying service was introduced through the Channel Tunnel. In Social Trends 27, Table 12.18 data was first reported on traffic travelling through the Tunnel. In 1995, 1.8 million visits to the UK were through the Channel Tunnel together with 1.9 million visits abroad.

The 1990s was the decade that saw the increase in the number of 'road-rage' incidence amongst car drivers, and this was reported on in Social Trends 28. Table 12.11 stated that in Great Britain women were almost as likely as men to say they had felt like swearing or gesturing but men were much more likely to have felt like committing the more dangerous forms of 'road-rage'. Not surprisingly people under the age of 35 were three times as likely as people aged 65 or over to have actually sworn or gestured at another driver, however, these younger drivers were only twice as likely as the older drivers to have felt like swearing or gesturing.

Social Trends 26 reported on what activities people carried out during a typical week. Table 13.2 (Table 1990.3 overleaf) showed that in 1995 men working full time spent 53 hours a week in Great Britain on either work, travel or study which was five hours more than women in full time work. However, these 
Table 1990.3

Time use: by employment status and gender, May 1995

\begin{tabular}{|c|c|c|c|c|c|c|c|}
\hline & \multicolumn{2}{|c|}{$\begin{array}{l}\text { In full-time } \\
\text { employment }\end{array}$} & \multicolumn{2}{|c|}{$\begin{array}{l}\text { In part-time } \\
\text { employment }\end{array}$} & \multicolumn{2}{|c|}{ Retired } & \multirow[b]{2}{*}{ All adults } \\
\hline & Males & Females & Males & Females & Males & Females & \\
\hline \multicolumn{8}{|l|}{ Weekly hours spent on } \\
\hline Sleep & 57 & 58 & 62 & 60 & 67 & 66 & 61 \\
\hline Free time & 34 & 31 & 48 & 32 & 59 & 52 & 40 \\
\hline Work, study and travel & 53 & 48 & 28 & 26 & 3 & 4 & 32 \\
\hline Housework, cooking and shopping & 7 & 15 & 12 & 26 & 15 & 26 & 16 \\
\hline Eating, personal hygiene and caring & 13 & 13 & 13 & 21 & 15 & 17 & 15 \\
\hline Household maintenance and pet care & 4 & 2 & 6 & 3 & 9 & 3 & 4 \\
\hline Free time per weekday & 4 & 4 & 6 & 4 & 8 & 7 & 5 \\
\hline Free time per weekend day & 8 & 6 & 8 & 6 & 10 & 8 & 8 \\
\hline
\end{tabular}

Source: Economic and Social Research Council Research Centre on Micro-social Change, from Omnibus Survey

women spent eight hours more than their male counterparts on housework, cooking or shopping each week. As a result of these differences, at weekends men in full-time employment had around two more hours a day of free time than women who worked full time, although on weekdays they have the same amount at nearly four hours of free time each day.

\section{The 2000s}

The year 2001 marked the end of the 20th century and the 30th birthday for Social Trends. The previous three decades had already shown the rate at which UK society was changing, and the impact that economic cycles, government policies and evolving technology had on people's lives.

The start of the 21st century coincided with an upturn in the UK economy. Gross domestic product (GDP), the UK National Accounts measure of overall level of activity in the economy, showed strong growth, and Social Trends began to highlight the early signs of a housing boom in the UK market. Past editions of Social Trends have demonstrated the mirroring of economic cycles and the housing market in the UK, with booms and slumps in one also occurring in the other.

The post-war housebuilding boom led to a shift in tenure patterns in the UK. We have already examined the right to buy legislation launched in the 1980s which proved extremely popular, and contributed to the substantial growth in the number of owner-occupied homes since the 1980s. In Social Trends 40, Figure 10.4 examines the rise in the owneroccupation in the UK. In quarter 2 (Q2) 2000, there were
17.0 million owner-occupied households in the UK, by Q2 2005 this figure had reached 17.7 million. Despite falling to 17.5 million in Q2 2009, owner-occupation still remained the dominant feature of UK tenure, accounting for 68 per cent of household tenure in this period.

In Social Trends 36, Figure 10.22 (Figure 2000.1) examined the average dwelling prices in the UK. There have been steep increases in house prices since the series began in 1980. In more recent years, in 2004 the average price paid by first-time

\section{Figure 2000.1}

\section{Average dwelling prices: ${ }^{1}$ by type of buyer \\ United Kingdom \\ $\mathrm{f}$ thousand}

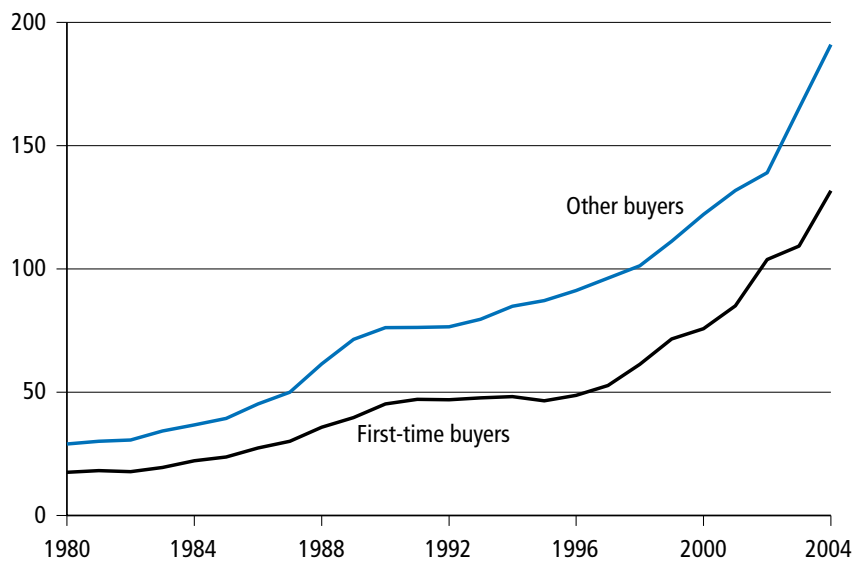

1 Uses simple average prices.

Source: Office of the Deputy Prime Minister 
buyers reached $\mathrm{f} 131,700,74$ per cent higher than in 2000 . For former owner-occupiers, the average price paid reached $f 191,000$ in 2004, 56 per cent higher than in 2000.

Directly linked to the average dwelling price are changes in the number of property transactions. The methodology used to calculate residential property transactions was changed in 2008, as a result the system only enables a consistent time series to be backdated to April 2005. Even over this limited period, Figure 10.17 in Social Trends 40 highlights the large increases in residential property transactions in the UK. There were 105,000 property transactions in May 2005. Transactions then increased sharply to a peak of 153,000 in December 2006. Housing market conditions changed substantially at the start of 2007, there were decreases in the number of property transactions almost every month throughout that year, the largest monthly decrease was between November 2007 and December 2007, with a 21 per cent fall in transactions from 131,000 to 104,000 . Similarly, Figure 6.10 in Social Trends 40 measures the amount of lending to individuals in the UK secured on dwellings. Mirroring the property boom, lending increased sharply from 2000 to a peak of $£ 33.3$ billion in the last quarter of 2003. Lending fell in 2004 but started to increase again in 2005 , to reach $£ 32.4$ billion in the last quarter of 2006. The amount of secured lending then decreased sharply from the last quarter of 2007 and following the announcement that the UK was officially in recession in January 2009 lending figures fell further and were $\mathrm{f} 1.9$ billion by the third quarter of 2009 .

People in the UK now travel more and further than 40 years ago. This is one aspect of what is known as our 'carbon footprint'. In order to moderate and reduce the negative impact that human activity has upon the environment, governments both at the UK and global level have developed environment-related policies. In Social Trends 38, Figure 11.15 (Figure 2000.2) examined the disposal of domestic and commercial waste in England. At the end of the 20th century, 84 per cent of the $\mathbf{2 4 . 6}$ million tonnes of municipal waste was disposed to landfill, while recycling accounted for 7 per cent of this total. During the 2000s, households have taken more accountability of environmental issues and by 2006/07, municipal waste disposed to landfill had fallen to 16.9 million tonnes, 58 per cent of the total amount of waste produced, while recycling had increased to 8.9 million tonnes, accounting for 31 per cent of total municipal waste.

In addition to improvements in recycling rates, renewable energy developments have been at the forefront of environmentally friendly campaigning. In Social Trends 40, Table 11.2 examines electricity generation by renewable

\section{Figure 2000.2}

\section{Management of municipal waste: by method \\ England}

Million tonnes

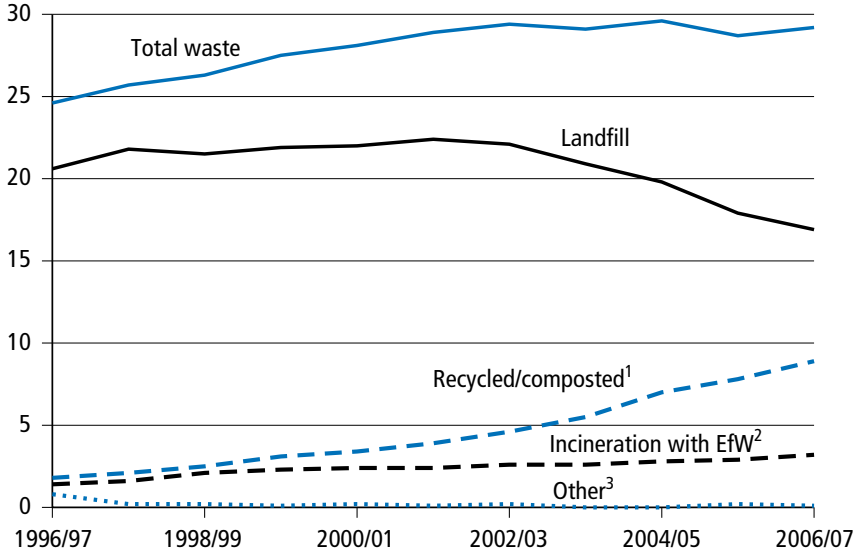

1 Includes household and non-household sources collected for recycling or for centralised composting; home composting estimates are not included in this total.

2 Energy from waste. Includes refuse derived fuel.

3 Includes incineration without energy from waste and other disposal that excludes any processing before waste is sent to landfill or materials reclamation.

Source: Department for Environment, Food and Rural Affairs

sources in the UK. In 2008, renewable energy accounted for 5.5 per cent of all electricity generated in the UK, the equivalent of 4.3 million tonnes of oil equivalent. This represented an increase of around 110 per cent since 2001. In both periods, biofuels accounted for the largest proportion of electricity generated from renewable sources.

We have already seen in the previous decades that rapid advances in technology have affected many aspects of people's lives. Undoubtedly, people today are more technologically minded than ever before, laptops, mobile phones and social networking sites appear to be a primary tool for arranging social activities. However, traditional activities such as watching television, reading and spending time with family and friends have not been completely abandoned in favour of new technology.

A particular focus of Social Trends 33 was to examine the concept of social capital and its impact upon society. One measure of social capital in this edition was data on 'neighbourliness' and the strength of community spirit.

Table 13.5 (Table 2000.3 overleaf) examined the number of times people speak to their neighbours and the number of people they know within their area.

The proportion of people who say they know many people in their neighbourhood increases with age. In Great Britain in 2000/01, 35 per cent of people aged between 16 and 29 said 
Table 2000.3

Indicators of neighbourliness: by age, 2000/01

\begin{tabular}{|c|c|c|c|c|c|c|}
\hline \multirow[t]{2}{*}{ Great Britain } & & & & & \multicolumn{2}{|r|}{ Percentages } \\
\hline & $16-29$ & $30-39$ & $40-49$ & $50-59$ & $60-69$ & 70 and over \\
\hline \multicolumn{7}{|c|}{ Frequency of speaking to neighbours } \\
\hline Daily & 17 & 25 & 21 & 28 & 39 & 43 \\
\hline $3-6$ days per week & 20 & 23 & 25 & 24 & 23 & 22 \\
\hline $1-2$ days per week & 32 & 31 & 37 & 32 & 27 & 23 \\
\hline Less than once per week & 30 & 21 & 17 & 16 & 11 & 12 \\
\hline \multicolumn{7}{|c|}{ Number of people known in the neighbourhood } \\
\hline Most/many & 35 & 39 & 48 & 50 & 54 & 57 \\
\hline A few & 51 & 54 & 48 & 47 & 44 & 41 \\
\hline None & 14 & 8 & 4 & 3 & 2 & 3 \\
\hline
\end{tabular}

Source: General Household Survey, Office for National Statistics

that they knew most or many people in their neighbourhood, compared with at least half of people aged 50 and over. Younger people were also the least likely of all age groups to speak to their neighbours on a daily basis. Almost a fifth (17 per cent) of people aged 16 to 29 reported doing this compared with more than two-fifths (43 per cent) of people aged 70 and over.

Individuals are also able to contribute to their community through volunteering. Table 13.16 in Social Trends 39 reported on the selected benefits from formal volunteering by age in England. Young people aged 16 to 34 were most likely of all age groups to feel that volunteering gave them a chance to gain new skills, enhance their employment prospect, gain a position in the community and get a recognised qualification. Older people aged 65 and over were most likely of all age groups to see volunteering as something that gave them the chance to meet people and make friends.

\section{Social Trends - Life begins at $\mathbf{4 0}$}

Throughout the decades Social Trends has remained a co-operative effort by the whole Government Statistical
Service. ONS are proud to publish Social Trends, and to continuously develop it. Thanks goes to all, both past and present, who contributed, developed and quality assured the content of Social Trends, allowing each edition to provide accessible statistics about UK society.

Following publication of Social Trends 40 , ONS intends to develop and launch web only editions of Social Trends in the future, with material being published throughout the year. This will provide more timely releases of statistics and commentary on changes in UK society. ONS is also planning to publish regular statistical reports highlighting particular areas of interest.

\section{Notes}

1 All statistics and sources presented in this article are as reported in the Social Trends edition quoted, and were correct at the time of publication. Methodological changes, revisions and survey design may have resulted in revised figures being published in more recent editions.

\section{Contact}

social.trends@ons.gov.uk

01633455931 